\title{
Molécula Imobiliária para o ensino de Genética
}

\author{
Molecular Monopoly for Genetics teaching \\ Monopolio Molecular para la enseñanza de Genética
}

Joana Andresa Campelo Santos

ORCID: https://orcid.org/0000-0001-6058-9943

Universidade Federal de Pernambuco, Brasil E-mail: joana.andresa@ufpe.br

José Rivaldo de Lima

ORCID: https://orcid.org/0000-0002-9937-8112 Universidade Federal de Pernambuco, Brasil E-mail: joserivaldo.lima@ufpe.br

Ana Paula Bernardo da Silva

ORCID: https://orcid.org/0000-0002-9088-0210

Universidade Federal de Pernambuco, Brasil

E-mail: paula.bernardo@ufpe.br

Raquel Kamila de França Melo

ORCID: https://orcid.org/0000-0002-7700-3133

Universidade Federal de Pernambuco, Brasil

E-mail: raquel.kamila@ufpe.br

Vaniele Aparecida da Silva

ORCID: https://orcid.org/0000-0001-7635-0451

Universidade Federal de Pernambuco, Brasil

E-mail: vaniele.silva@ufpe.br

Jeanderson Marcelino da Silva

ORCID: https://orcid.org/0000-0001-7051-1592

Universidade Federal de Pernambuco, Brasil

E-mail: jmarcelino.silva@yahoo.com

Meykson Alexandre da Silva

ORCID: https://orcid.org/0000-0003-2895-0270

Universidade Federal de Pernambuco, Brasil E-mail: meykson.silva@ufpe.br

Claudia Rohde

ORCID: https://orcid.org/0000-0002-0977-9239

Universidade Federal de Pernambuco, Brasil

E-mail: claudia.rohde@ufpe.br

José Eduardo Garcia

ORCID: https://orcid.org/0000-0002-1741-4547

Universidade Federal de Pernambuco, Brasil

E-mail: joseeduardo.garcia@ufpe.br

\begin{abstract}
Resumo
Molécula Imobiliária é uma proposta de jogo de tabuleiro para desenvolver a aprendizagem de conceitos de Genética aos estudantes, que irão trabalhar em grupos e trocar informações entre si. O desafio é responder as perguntas do jogo de forma correta, ganhar o máximo de moedas e comprar nucleotídeos para formar a maior molécula de DNA. Quanto maior a quantidade de moedas adquiridas, maior a quantidade de nucleotídeos e, consequentemente, a possibilidade de o grupo ganhar o jogo, e melhorar seu conhecimento sobre os temas de Genética abordados. Nesse estudo, apresentamos nosso produto educacional para o ensino de Ciências e Biologia, bem como avaliamos a jogabilidade deste tabuleiro. Nesse sentido, a Molécula Imobiliária, constou ser um bom material paradidático e que contribui no processo criativo e motivador no ensino e aprendizagem acerca de determinados conceitos da Genética no Ensino Médio. Esta proposta de jogo, contribuiu para a construção coletiva do conhecimento, assim como, o desenvolvimento de outras habilidades relevantes para formação de um discente, como trabalho em equipe, liderança e colaboração. Dessa forma, concluímos que o jogo atende a sua proposta, por ser um instrumento didático facilitador e lúdico para o ensino da Genética e ainda contribui como alternativa metodológica docente perante as diversas aplicabilidades possíveis.
\end{abstract}

Palavras-chave: DNA; Jogo didático; Tabuleiro; Replicação; Transcrição. 


\begin{abstract}
Molecular Monopoly is a board game proposal to develop students learning Genetics concepts, who will work in groups and exchange information with each other. The challenge is to answer the game's questions correctly, earn the most coins, and buy nucleotides to form the largest DNA molecule. The greater the amount of coins purchased, the greater the number of nucleotides and, consequently, the possibility for the group to win the game, and improve their knowledge of the Genetics topics addressed. In this study, we present our educational product for teaching Science and Biology, as well as evaluating the gameplay of this board. Thus, Molecular Monopoly proved to be a good material for teaching and that contributes to the creative and motivating process in teaching and learning about certain concepts of Genetics in high school. This game proposal contributed to the collective construction of knowledge, as well as the development of other relevant skills for the formation of a student, such as teamwork, leadership and collaboration. Thus, we conclude that the game meets its proposal, as it is a facilitating and playful didactic tool for the teaching of Genetics and also contributes as a teaching methodological alternative in view of the various possible applications.
\end{abstract}

Keywords: DNA; Didactic game; Board; Replication; Transcription.

\title{
Resumen
}

Monopolio Molecular es una propuesta de juego de mesa para desarrollar estudiantes que aprenden conceptos de Genética, que trabajarán en grupos e intercambiarán información entre ellos. El desafío es responder correctamente a las preguntas del juego, ganar la mayor cantidad de monedas y comprar nucleótidos para formar la molécula de DNA más grande. Cuanto mayor sea la cantidad de monedas compradas, mayor será el número de nucleótidos y, en consecuencia, la posibilidad de que el grupo gane el juego y mejore su conocimiento de los temas de Genética abordados. En este estudio, presentamos nuestro producto educativo para la enseñanza de la Ciencia y la Biología, así como para evaluar la jugabilidad de este tablero. En este sentido, Monopolio Molecular, resultó ser un buen material para la docencia y que contribuye al proceso creativo y motivador en la enseñanza y aprendizaje de ciertos conceptos de Genética en el bachillerato. Esta propuesta de juego, contribuyó a la construcción colectiva de conocimientos, así como al desarrollo de otras habilidades relevantes para la formación de un alumno, como el trabajo en equipo, el liderazgo y la colaboración. Así, concluimos que el juego cumple con su propuesta, ya que es una herramienta didáctica facilitadora y lúdica para la enseñanza de la Genética y que aún contribuye como alternativa metodológica didáctica ante las diversas aplicaciones posibles.

Palabras clave: DNA; Juego didáctico; Juego de mesa; Replicación; Transcripción.

\section{Introdução}

Na segunda metade do século XIX, Gregor Mendel (1822-1884) publicou uma pesquisa precursora que contribuiu de maneira decisiva para os experimentos de melhoramento genético e para a compreensão dos princípios da hereditariedade, embora na época seu trabalho não tenha sido devidamente explicado e explorado (Brandão, 2009).

Três décadas depois deste achado, três biologistas (Hugo de Vries, Erich von Tschermak e Karl Correns), separadamente, descobriram os trabalhos de Mendel. A "redescoberta" das leis mendelianas permitiram o desenvolvimento da genética como uma nova ciência. Cerca de cinco décadas depois, com a elucidação da estrutura tridimensional do Ácido Desoxirribonucleico (1953), famosa dupla hélice de Watson e Crick e posterior Nobel em Medicina (1962), a genética tem um avanço, sendo consolidada como ciência (Veloso, 2003). Estes avanços vêm contribuindo consideravelmente em áreas fundamentais e favorecendo a sobrevivência humana, como pode ser visto na otimização de diagnósticos e medidas terapêuticas de doenças, na produção de alimentos, medicamentos, hormônios e vacinas (Borém \& Santos, 2001).

Dentro deste contexto, a Genética e a Biologia Molecular são apontadas como as áreas de conhecimento que terão contribuições relevantes para a solução de grande parte dos problemas mundiais. No entanto, atualmente estas duas ciências já colaboram de maneira significativa com estudos atuais e, com o auxílio da tecnologia, tornou possível os estudos com sequenciamento de genes, clonagem de organismos, produção de organismos geneticamente modificados entre outros (Luna, 2011).

Por outro lado, esse desenvolvimento e avanço da Ciência e da Biotecnologia afetam diretamente toda a sociedade, gerando inúmeras discussões sobre seus impactos e trazendo consigo diversas implicações éticas no âmbito religioso, político e social. Nesse contexto, surgem inúmeras indagações que permeiam a sociedade, como: “Será que devemos produzir organismos 
geneticamente modificados? Será que há riscos?” ou "será que a utilização de plantas geneticamente modificadas pode acarretar o aparecimento de superpragas?" (Luna, 2011).

Nesse sentido, é de extrema importância que sejam formados cidadãos capazes de discutir questões éticas e morais sobre estes temas que englobam conhecimentos da genética, demonstrando assim, a importância do ensino destes temas de forma adequada nas escolas (Luna, 2011).

De acordo com a Lei de Diretrizes e Bases da Educação Nacional (LDB) n ${ }^{\circ}$ 9394/96, no artigo $9^{\circ}$ onde fala em estabelecer, em colaboração com os Estados, o Distrito Federal e os Municípios, as competências e diretrizes para a educação infantil, ensino fundamental e médio, que nortearão os currículos e seus conteúdos mínimos, de modo a assegurar formação básica comum para todos os cidadãos e proporcionando o desenvolvimento dos discentes de forma plena, considerando para tanto, aspectos da cidadania, da dignidade, do direito à informação, do acesso aos bens culturais produzidos pela humanidade, da socialização e do atendimento dos alunos visando à sobrevivência e o desenvolvimento da sua identidade (Brasil, 2013).

Atualmente, entende-se como necessária uma aprendizagem com significados, que promova sentido na vida dos estudantes. Os Parâmetros Curriculares Nacionais (PCN) salientam que a escola precisa estar em consonância com as demandas da comunidade, sendo necessária a exploração de conteúdos que interfiram na vida dos estudantes ou são abordadas em seu cotidiano (Brasil, 1998).

Nesse sentido, o ensino de Genética tem sido apontado como uma necessidade na formação de jovens conscientes e capazes de tomar decisões em relação à sua própria vida, contribuindo também para a compreensão de diferenças individuais humanas, assim como, das novas tecnologias e inovações que envolvem essa ciência de base (Barnir, 2010).

No entanto, a aprendizagem da Genética é complexa, pois envolve uma rede de conceitos que o estudante precisa consolidar para construir significativamente seus conhecimentos (Silveira, 2008, Carboni \& Soares, 2011). Um conceito equivocado pode ser um fator decisivo para o não sucesso do indivíduo frente à uma situação-problema, sendo necessário o diagnóstico e mediação pelo professor para identificação dessas fragilidades, a fim de construir de forma coerente e substancial os conceitos sobre temas da Genética, partindo das ideias prévias dos discentes, bem como proporcionando estratégias e situações de aprendizagem que contemplem a construção do conhecimento biológico (Silveira, 2008).

Pesquisas com o objetivo de verificar a compreensão sobre os conteúdos da Genética e questões referentes às suas aplicações na saúde e tecnologia para alunos no fim do ensino médio, revelaram que nem mesmo os conceitos básicos de Genética (por exemplo: gene e cromossomo) ou a finalidade dos processos de mitose e de meiose, são compreendidos pelos estudantes no final dos anos de escolaridade obrigatória (Bugallo, 1995; Lewis \& Wood-Robinson, 2000).

Moreira \& Silva (2001) enfatizaram que para muitos professores a Genética é um assunto relativamente novo, pouco discutido em sua formação acadêmica, por isso, seu ensino vem sendo feito de maneira superficial nas escolas, gerando muitas dificuldades por parte dos alunos para compreender até mesmo os conceitos básicos. Entretanto, os professores de Ciências e de Biologia devem estar cientes da importância da educação científica de seus alunos e, ao ensinar, devem promover a formação do entendimento da importância das ciências na sociedade, buscando sempre a melhor formação para a educação de seus alunos (Fumagalli, 1998).

Embora o ensino de Biologia seja caracterizado muitas vezes por uma aprendizagem memorística, a docência de Biologia no Ensino Médio deve proporcionar atividades dinâmicas efetivas (Benedetti, Diniz \& Nishida, 2005). Atividades estas, que consigam tornar o ambiente de sala de aula em um espaço para a promoção, encorajamento e interesse dos estudantes acerca do conteúdo (Conceição, Mota \& Barguil, 2020).

Nesse contexto, o educador deve aplicar alternativas que auxiliem o processo de ensino e aprendizagem com a utilização de metodologias que diversifiquem as experiências em sala de aula, para assim desenvolver competências nos alunos, integrando- 
os como peças-chave no processo de ensino-aprendizagem (Moratori, 2003; Jann \& Leite, 2010).

Nessa conjuntura, os jogos didáticos se mostram como recursos pertinentes, e que os professores podem utilizar como instrumento auxiliar para estimular seus alunos ao aprendizado de forma prazerosa, lúdica e atraente (Campos, Bortoloto \& Felício, 2003). Os jogos podem ser inseridos de forma eficaz na educação escolar, e utilizados de forma construtiva não apenas em relação ao conteúdo, mas também para desenvolver a socialização, a cognição, a cooperação, a interdependência, e a transmissão de conteúdos de forma prazerosa (Neves, Campos \& Simões, 2008). Destes momentos lúdicos que o jogo proporciona, os conhecimentos ficam mais fáceis de serem compreendidos pelos estudantes, podendo ser alcançada uma aprendizagem significativa em decorrência da maior propensão dos alunos a se envolverem e aprenderem (Silvia \& Bianco, 2020).

Assim, sabendo da importância da utilização de jogos na sala de aula como metodologia, e para poder proporcionar aos alunos uma aprendizagem mais prazerosa, lúdica e atraente, o presente trabalho apresenta uma proposta de jogo didático de tabuleiro, intitulado como "Molécula Imobiliária", para ser desenvolvido durante o ensino de Genética, abordando as estruturas químicas (DNA e RNA) envolvidas na transmissão de caracteres hereditários e os processos de replicação e transcrição.

\section{Metodologia}

\subsection{Desenho do estudo}

O presente trabalho usa a modalidade estudo de caso/relato de experiência, de natureza qualitativa, conforme Gil (2017), perfazendo a descrição do produto educacional e sua jogabilidade para o ensino de Genética. A estrutura da Molécula Imobiliária seguiu aspectos do Game Thinking, que tem como objetivos majoritários a resolução de problemas complexos (como as dificuldades em aprender assuntos abstratos da Genética), bem como colocar os indivíduos como protagonistas na resolução desse processo (Brussi, 2014).

\subsection{Como funciona a Molécula Imobiliária?}

Para esse jogo serão necessários: um tabuleiro da Molécula Imobiliária (Figura 1), quatro pinos coloridos, lista de perguntas contextualizadas, dado, moedas (Figura 2), representações de moléculas de nucleotídeos (Figura 3), cartas de sorte ou azar (Figura 4) e perguntas diagnósticas. O objetivo do jogo é fazer a maior dupla fita de DNA. 
Research, Society and Development, v. 10, n. 4, e10310413890, 2021

Figura 1. Imagem do tabuleiro da Molécula Imobiliária.

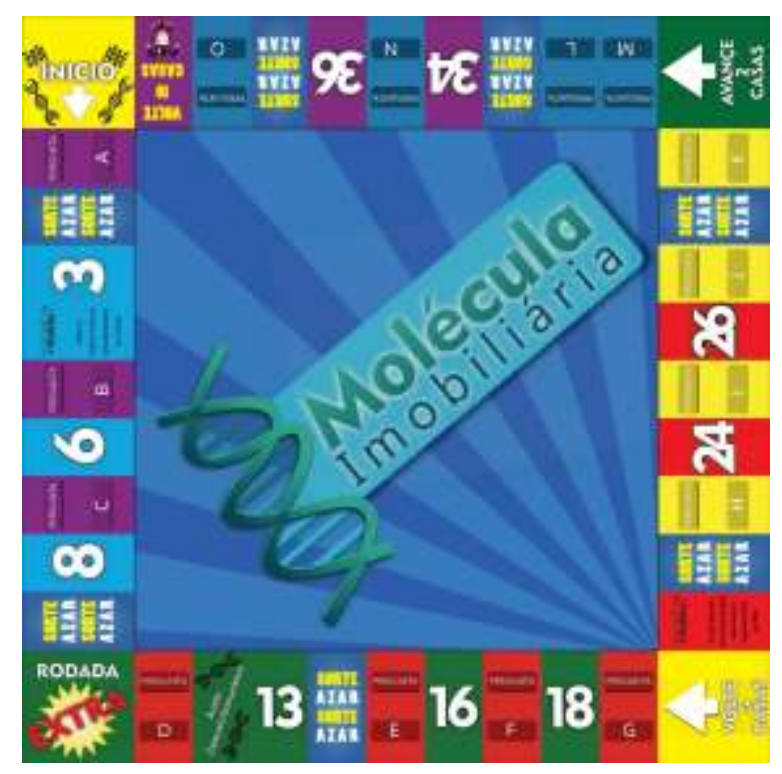

Fonte: Autores (2021).

Figura 2. Representativo de moedas para compra de nucleotídeos (é recomendado cortar na linha pontilhada e colar em papel guache ou cartolina para ficar mais resistente).

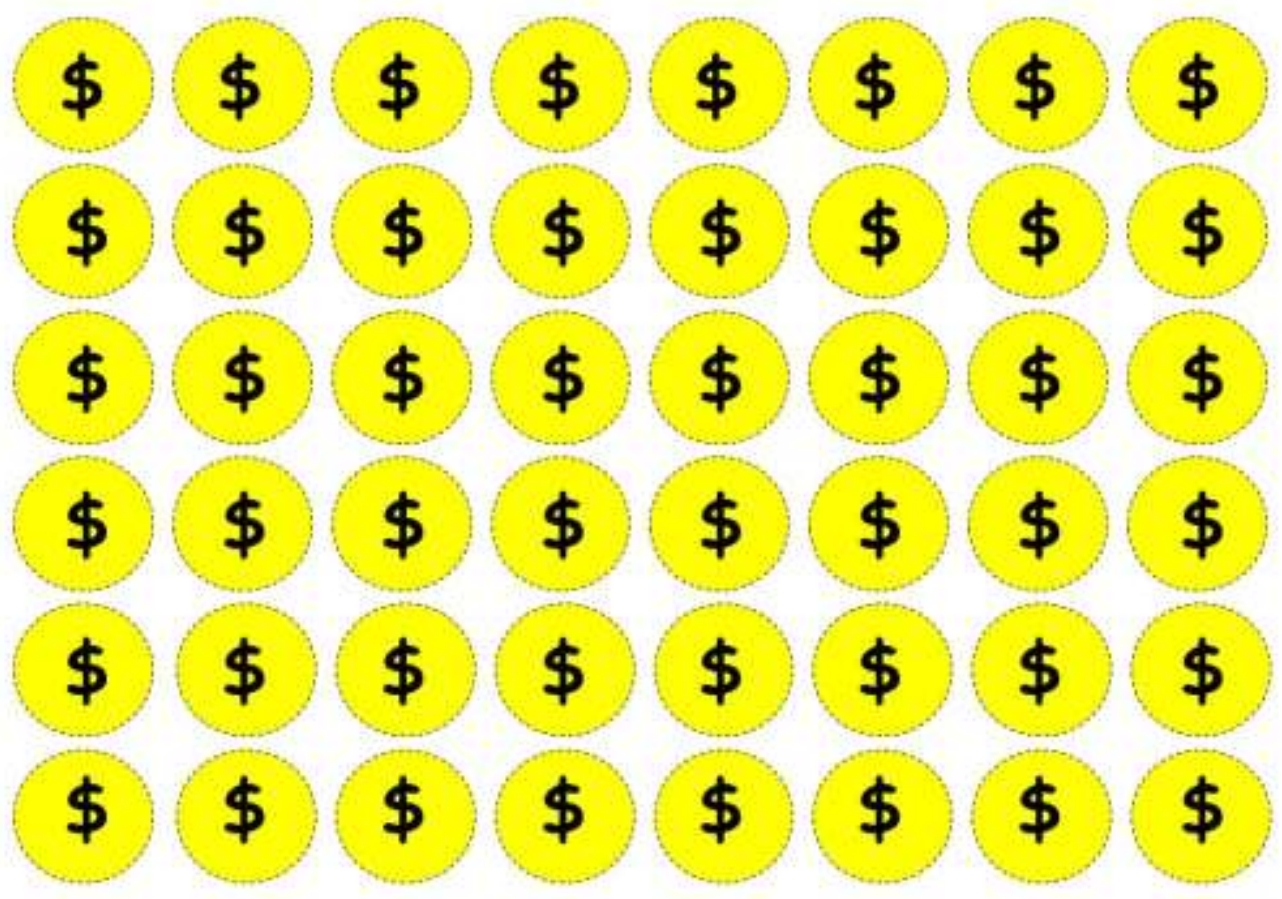

Fonte: Autores (2021). 
Research, Society and Development, v. 10, n. 4, e10310413890, 2021

(CC BY 4.0) | ISSN 2525-3409 | DOI: http://dx.doi.org/10.33448/rsd-v10i4.13890

Figura 3. Representações de moléculas de nucleotídeos (é recomendado cortar na linha pontilhada e colar em papel guache ou cartolina para ficar mais resistente).

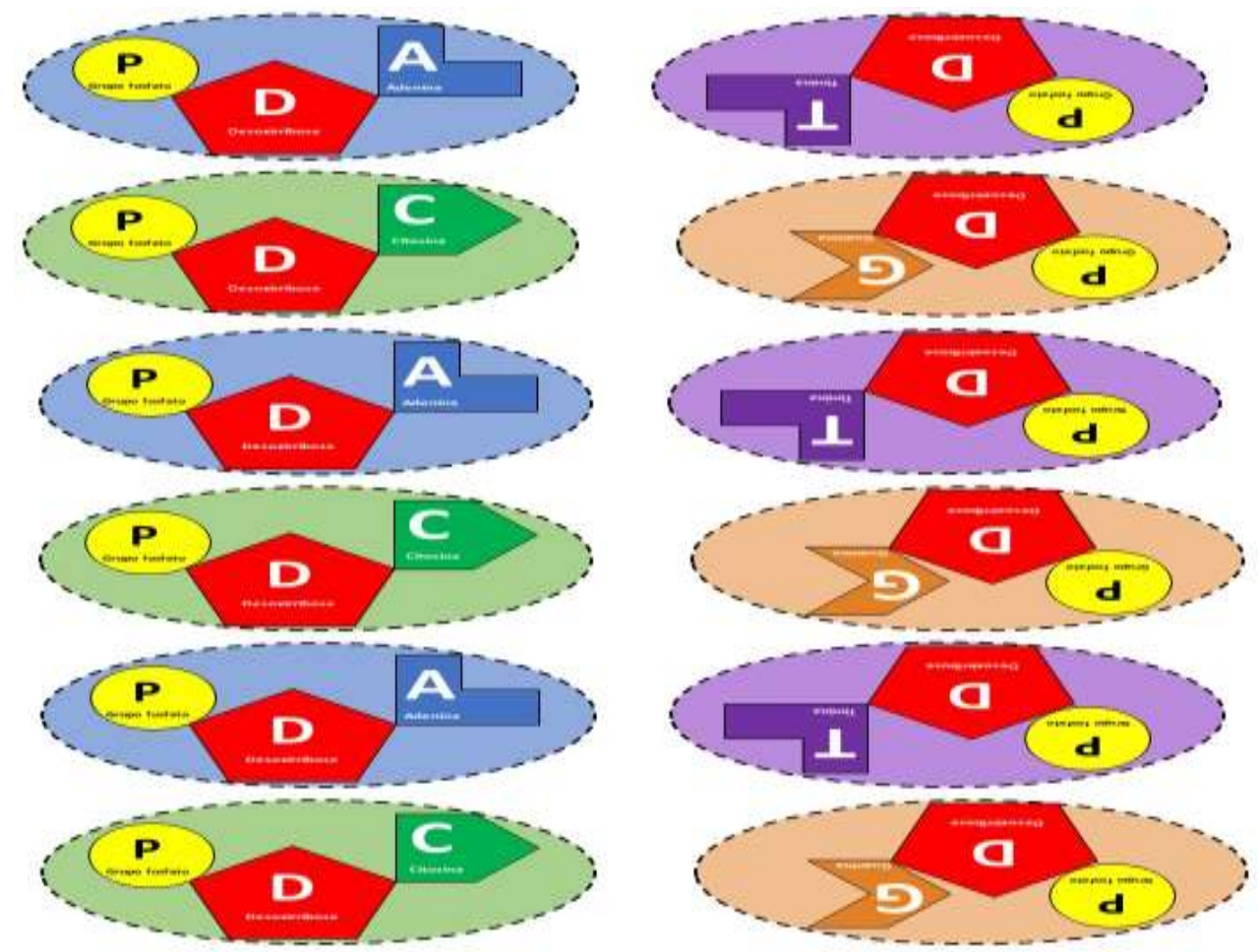

Fonte: Autores (2021). 
Figura 4. Cartas de Sorte ou Azar (é recomendado cortar na linha pontilhada e colar em papel guache ou cartolina para ficar mais resistente).

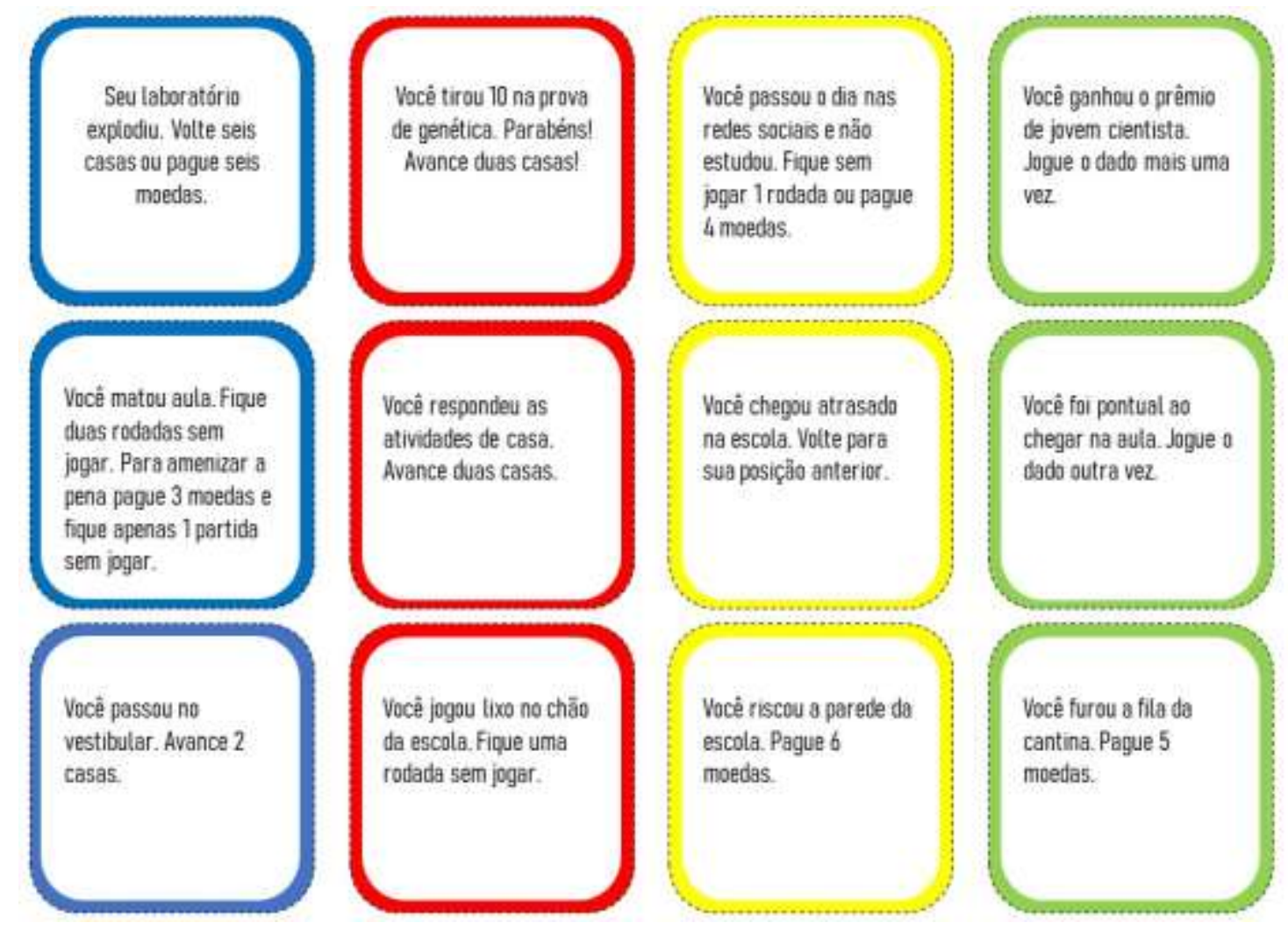

Fonte: Autores.

\subsection{Modo de jogar}

A Molécula Imobiliária é fundamentada na compra de moléculas de nucleotídeos. O jogo consiste em instigar os alunos a responderem, em equipe, questões didáticas sobre Genética, colocando em prática os conhecimentos adquiridos nas aulas de Biologia, durante o Ensino Médio.

1. Inicialmente, a turma é dividida em quatro grupos, contendo um representante por grupo. Com a sala em círculo, e o tabuleiro localizado no centro, os representantes ficam responsáveis por movimentar os seus respectivos pinos.

2. O jogo é dividido em dois momentos. No primeiro, serão utilizadas questões mais simples, que são de suma importância para relembrar conceitos fundamentais da Genética. As perguntas simples são apenas para acúmulo de patrimônio/ moedas. No momento seguinte, serão apresentadas questões mais contextualizadas e apresentadas no tabuleiro.

3. No primeiro momento, as perguntas mais simples estarão escritas em cartelas, e ficarão guardadas dentro de uma sacola, para que o representante do grupo pegue, aleatoriamente, uma a cada rodada, e leve ao seu grupo para que responda.

4. Para todas as perguntas, existe um limite de tempo de 2 a $3 \mathrm{~min}$. Dependendo da complexidade da pergunta.

5. O valor recebido por resposta correta é simbólico. Dependendo da questão, será atribuído um valor de 1 a 4 moedas por resposta correta. $\mathrm{O}$ valor poderá ser determinado para cada questão pelo professor.

6. Em casos de o grupo não conseguir responder à questão, a pergunta deve ser passada para outro grupo seguindo a ordem (exemplo, se o grupo 2 não soube responder, a pergunta deverá ser passada ao grupo 3) e o mesmo receberá as moedas se acertar.

7. Após a resolução de todas as questões diagnósticas, o jogo no tabuleiro irá começar. 
8. No segundo momento, o grupo 1 deverá jogar o dado. Caso caia em uma casa referente a alguma pergunta, e se ela for respondida de forma correta, o grupo avançará a(s) casa(s) dependendo do número sorteado no dado, ganhando a quantia indicada de moedas. No caso de respostas equivocadas, o grupo ficará na mesma casa do tabuleiro e a pergunta será passada ao grupo seguinte.

9. Caso o grupo seguinte acerte, ele jogará o dado para saber quantas casas irão avançar. Se o grupo seguinte não acertar, a pergunta será passada para o grupo posterior.

10. A ordem de partida dos grupos deverá ser o grupo 1, 2, 3 e 4 respectivamente.

11. No tabuleiro existem alguns empecilhos para os jogadores, como as casas de azar, com mensagens de voltar casas, tornando o jogo mais dinâmico e divertido.

12. Existem as "casas do bem" que favorecem os jogadores. A casa "Você sabia?" Permite que o grupo avance casas sem precisar responder perguntas, "avance casas" e "rodada extra" são opções que oportunizam aos grupos passarem na frente de outros.

13. O jogo acaba quando restar apenas um grupo no corredor do tabuleiro. Ao fim, os grupos irão trocar as moedas recebidas por nucleotídeos, vencendo aquele que montar a maior molécula de DNA. Vale ressaltar que os alunos deverão prestar atenção em quais nucleotídeos devem comprar, para formar, corretamente, duas fitas complementares, obedecendo os pareamentos de bases A-T e C-G.

\subsection{Sugestões para o professor}

1. É recomendável que antes do início do jogo sejam definidos os representantes de cada grupo, para uma maior organização. É também indispensável deixar claro aos alunos que a resolução das questões será uma contribuição conjunta, de todos do grupo.

2. Para ganhar tempo no primeiro momento do jogo (nas perguntas iniciais, antes de abordar o tabuleiro), sugere-se que os representantes de cada grupo peguem, todos em simultâneo, cada uma das perguntas, e que eles tenham um tempo determinado para respondê-las em grupo.

3. Quando o grupo responder à questão, os representantes deverão ler em voz alta as perguntas para a turma. Assim, todos os alunos terão a chance de aprender e o jogo alcançará um de seus objetivos.

4. O professor poderá instigar os alunos para que apresentem suas opiniões acerca das questões, de modo que haja troca de opiniões na turma, e que todos contribuam no processo de aprendizagem.

5. O jogo poderá ser usado pelo professor como um método avaliativo. Ele poderá utilizá-lo, por exemplo, após a abordagem do conteúdo em sala de aula, ou, poderá aplicá-lo para uma aula de revisão pré-vestibular, sobre determinado conteúdo.

\subsection{Exemplos de Perguntas diagnósticas}

1. Complete a seguinte frase: A Genética é o estudo da

A) reprodução e hereditariedade;

B) hereditariedade e variação de ácidos nucléicos;

C) variação de ácidos nucléicos e reprodução;

D) hereditariedade e variação das características herdadas;

E) variação de indivíduos de uma mesma espécie e reprodução.

Resposta: letra D. Se dá pela hereditariedade (conjunto de processos biológicos que asseguram que cada ser vivo receba e 
transmita informações genéticas através da reprodução) e pela variação de diferenças morfológicas, comportamentais e fisiológicas de indivíduos de uma mesma espécie, ou entre espécies diferentes.

2. Qual(s) da(s) afirmações está(ão) correta(s):

I- O DNA é um polímero e seus nucleotídeos são monômeros;

II- O DNA é um monômero e seus nucleotídeos são polímeros;

III- O DNA é composto por subunidades de adenina, timina, citosina e guanina.
A) I e II
B) I e IIIC) apenas I
D) II e III
E) apenas II

Resposta: letra B

3- Quais são as subunidades que compõe o RNA?

Resposta: ADENINA, URACILA, GUANINA E CITOSINA.

4- Giovana, ao brincar de escolinha com suas bonecas, começou a explicar sobre DNA e RNA, e usou como exemplo duas barras de chocolate. Para ela, as duas barras unidas seriam o RNA. Ela comeu uma barra para representar o DNA. A explicação de Giovana para suas bonecas está certa? Explique. Resposta: Não. Porque o DNA é composto por duas fitas, e o RNA por apenas uma. E suas barras de chocolate, logicamente, estavam representando as fitas.

5- Sabemos que os nucleotídeos são subunidades de DNA e RNA. Mas falando isoladamente do DNA, sabemos que o mesmo é composto por quatro distintos nucleotídeos e que todos são compostos por três estruturas. Quais são as três estruturas que os compõem o DNA? Quais são as estruturas presentes independente do nucleotídeo, e qual é a diferença que distingue os tipos de nucleotídeos? Resposta: Os nucleotídeos do DNA são compostos por: um grupo fosfato, um açúcar/pentose (desoxirribose) e a base nitrogenada. O grupo fosfato e o açúcar estão sempre presentes, em todos os tipos de nucleotídeos, mas as bases nitrogenadas são diferentes nos diferentes nucleotídeos. Se o nucleotídeo for uma Timina, a base será uma timina. Se for um nucleotídeo Citosina, a base será Citosina, e assim por diante.

6- Quais são dois grupos de classificação dos nucleotídeos presentes no DNA ou RNA? Cite seus nomes e seus representantes.

Resposta: Pirimidinas: composto por citosina, timina e uracila. Purinas: composto por adenina e guanina.

7- Qual a diferença estrutural entre as pirimidinas e purinas?

Resposta: A diferença é quantidade de anéis heterocíclicos que elas possuem na sua estrutura química. As pirimidinas possuem um anel, enquanto as purinas possuem dois anéis.

8- Qual a alternativa correta?

A) O DNA forma uma estrutura dupla hélice, em forma de um círculo;

B) O DNA forma uma estrutura dupla hélice, em forma de um quadrado;

C) O DNA forma uma estrutura dupla hélice, em forma de escada caracol.

\section{Resposta: Letra C}

9- Sabe-se que o DNA e RNA são compostos por vários nucleotídeos ligados entre si. Cite quais são os pares de nucleotídeos 
tem que se ligam, para formar a macromolécula de DNA ou RNA.

Resposta: No DNA: $\mathrm{C}=\mathrm{G}$ e $\mathrm{A}=\mathrm{T}$. No RNA: $\mathrm{C}=\mathrm{G}$ e $\mathrm{A}=\mathrm{U}$.

10- Quais os tipos de ligações químicas necessárias para a formação do DNA ou do RNA? Resposta: Ligações de hidrogênio e ligações fosfodiéster.

11- Ainda sobre as ligações químicas que ocorrem na dupla hélice do DNA, qual a alternativa correta?

A) As ligações fosfodiéster são ligações longitudinais e covalentes;

B) As ligações fosfodiéster são ligações horizontais e iônicas;

C) As ligações fosfodiéster são ligações longitudinais e iônicas;

D) As ligações fosfodiéster são ligações horizontais e covalentes.

Resposta: letra A

12- Sobre as ligações de hidrogênio que ocorrem na dupla hélice do DNA:

I- São ligações horizontais;

II- Representam ligações covalentes entre um fosfato e um açúcar;

III- Ligam fitas antiparalelas.

Qual alternativa está correta:
A) I e II
B) I e III
C) II e III
D) apenas I
E) apenas III

Resposta: Letra B. (o item II não está correto porque a ligação de hidrogênio só ocorre entre as bases.)

13- Você acredita que todas as formas de vida usam apenas o DNA como seu material genético? Ou há formas de vida que usam o RNA? Dê um exemplo se isso for verdadeiro. Resposta: Embora o DNA seja o material genético dos maiores dos organismos vivos, existem sim alguns vírus que utilizam apenas o RNA como seu material genético.

14- Sobre o RNA qual a alternativa incorreta:

A) O RNA é o "guia” para a síntese do DNA na maioria dos organismos;

B) No RNA a timina é substituída pela Uracila;

C) Ela é uma molécula menos estável que o DNA;

D) Ela dura no máximo dentro de uma célula 10 segundos

Resposta: letra A (em alguns vírus, o RNA é sim a molécula guia para a síntese de DNA, feito por meio da "transcrição reversa" e da atuação da enzima transcriptase reversa, que está presente somente nestes organismos).

15- Tenho um açúcar com um oxigênio a menos, meu fosfato está presente, ganhei um anel de noivado, mas não posso aceitar, pois mudaria meu grupo. Sou tímida, porém hoje quis me apresentar, quem sou eu? Resposta: Timina

16- Ana casou com Carlos, e Gabriela com Thiago. Levando em consideração as inicias dos nomes e as bases nitrogenadas que possuem as mesmas iniciais, aponte o erro. Resposta: As iniciais dos nomes simbolizam os nucleotídeos, logo, Ana teria que se casar com Thiago, e Gabriela com Gustavo. $\mathrm{A}=\mathrm{T}$ e $\mathrm{G}=\mathrm{C}$. 


\subsection{Exemplos de perguntas que podem ser utilizadas no decorrer do tabuleiro.}

Pergunta A - Complete o quadro referente aos ácidos nucléicos estudados, legendando-o.

\begin{tabular}{|c|c|c|}
\cline { 2 - 3 } \multicolumn{1}{c|}{} & DNA & RNA \\
\hline Grupo fosfato & A & Ácido fosfórico \\
\hline B & Desoxirribose & C \\
\hline
\end{tabular}

Pergunta B - O que significa:
a) DNA
b) RNA

Pergunta C - Numa molécula de DNA, a quantidade de...

a) Adenina mais timina é igual à de citosina mais guanina.

b) Citosina mais uracila é igual à de timina mais adenina.

c) Uracila mais adenina é igual à de citosina mais guanina.

d) Guanina mais timina é igual à de citosina mais uracila

e) Adenina mais citosina é igual à de guanina mais timina.

Pergunta D - O esquema abaixo representa duas cadeias de ácidos nucleicos. Podemos concluir que...

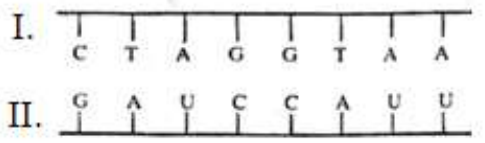

a) I e II correspondem a duas moléculas de RNA.

b) I e II correspondem a duas cadeias de uma molécula de RNA.

c) I e II correspondem a duas cadeias de uma molécula de DNA.

d) I corresponde a uma cadeia de DNA e II a uma cadeia de RNA.

e) I corresponde a uma cadeia de RNA e II a uma cadeia de DNA.

Pergunta E - Observa a figura que se segue, referente a modelos de replicação do DNA.
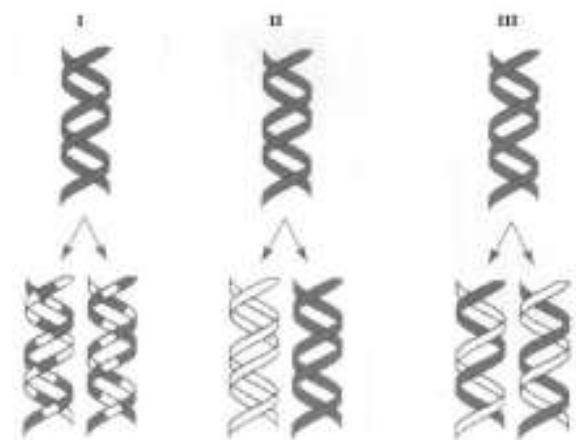

Fonte: UFRGS (2017) (Disponível em: https://brainly.com.br/tarefa/17483188).

Qual o modelo aceito atualmente, e como ele se caracteriza? 
Pergunta F - A composição dos seres vivos contém nitrogênio que é essencial para a formação de:
A) Açúcares de reserva
B) Glicogênio
C) Ácidos Nucleicos
D) Lipídios de reserva
E) Água

Pergunta G - Cinco amostras com ácidos nucleicos foram analisadas quimicamente e apresentaram os seguintes resultados:
I- $1^{\mathrm{a}}$ amostra: ribose
II- $2^{\mathrm{a}}$ amostra: timina
III- $3^{\mathrm{a}}$ amostra: dupla hélice

IV- $4^{\text {a }}$ amostra: uracila

V- $5^{\mathrm{a}}$ amostra: $20 \%$ de guanina e $30 \%$ de timina

Entre estas amostras, quais itens se referem ao DNA?
A) Apenas I e II
B) Apenas I e III
C) Apenas II e III
D) Apenas II e IV
E) Apenas II e V

Pergunta H - (UDESC 2016) Analise as proposições, em relação aos ácidos nucleicos, e assinale (V) para verdadeira e (F) para falsa.

( ) Os ácidos nucleicos são moléculas gigantes formadas por unidades chamadas de nucleotídeos.

( ) O RNA transportador é formado a partir de regiões específicas do DNA.

( ) O RNA ribossômico associado com proteínas forma os ribossomos.

( ) O DNA apresenta-se altamente condensado nas células procarióticas.

Pergunta I - Não é característica do DNA:
A) O açúcar com cinco átomos de carbono
B) A presença de ácido fosfórico
C) É polinucleotídeo
D) Ocorre nos cromossomos
E) A presença das bases nitrogenadas uracila, guanina, citosina e adenina

Pergunta J - Watson e Crick elucidaram o modelo da estrutura da molécula de DNA. Dentre as afirmações abaixo, assinale a alternativa CORRETA:
A) Uma cadeia simples de DNA é constituída por uma desoxirribose ligada a um fosfato e a um aminoácido.
B) A polimerização de uma fita simples de DNA é dita como semiconservativa, pois independe da existência de uma fita molde.
C) Os nucleotídeos são polimerizados por meio de ligações fosfodiéster entre o fosfato e a base nitrogenada.
D) Duas cadeias simples de DNA formam uma dupla-hélice, por meio da formação de pontes de hidrogênio entre as bases nitrogenadas.
E) As duas cadeias de uma dupla-hélice possuem a mesma orientação, e suas sequencias de bases são complementares.

Pergunta K - A sequência de nucleotídeos ATGCACCT forma um segmento de DNA dupla hélice ao se ligar à fita complementar:
A) AUGCACCU B) UACGUGGA C) TACGAGGA D) TCCACGTA
E) ATGCACCT

Pergunta L - A estrutura do nucleotídeo de DNA se diferencia do RNA pela presença de:

A) Desoxirribose e uracila no RNA; Ribose e timina no DNA 

B) Desoxirribose e uracila no RNA; Desoxirribose e citosina no DNA
C) Ribose e timina no RNA; Desoxirribose e uracila no DNA
D) Ribose e Uracila no RNA; Desoxirribose e timina no DNA
E) Ribose e timina no RNA; Ribose e adenina no DNA

Pergunta M - De acordo com a replicação do DNA pode afirmar, que:
A) A replicação do DNA é conservativa, isto é, a fita dupla filha é recém-sintetizada e o filamento parental é conservado.
B) A replicação de DNA é dispersiva, isto é, as fitas filhas contêm DNA recém-sintetizado e parentais em cada uma das fitas.
C) A replicação é semiconservativa, isto é, as fitas filhas consistem de uma fita parental e uma recém-sintetizada
D) A replicação do DNA é conservativa, isto é, as fitas filhas consistem de moléculas de DNA parental.
E) A replicação é semiconservativa, isto é, as fitas filhas consistem de uma fita molde e uma fita codificadora.

Pergunta N - (ENEM 2005) Um fabricante afirma que um produto disponível comercialmente possui DNA vegetal, elemento que proporcionaria melhor hidratação dos cabelos. Sobre as características químicas dessa molécula essencial à vida, é correto afirmar que o DNA) de qualquer espécie serviria, já que têm a mesma composição.

b) de origem vegetal é diferente quimicamente dos demais, pois possui clorofila.

c) das bactérias poderia causar mutações no couro cabeludo.

d) dos animais encontra-se sempre enovelado e é de difícil absorção.

e) de características básicas assegura sua eficiência hidratante.

Pergunta O - (UECE 2015) A molécula de DNA armazena informação genômica que é transcrita e traduzida por mecanismos elegantes como os de transcrição e tradução. Entretanto, entre os distintos indivíduos biológicos construídos por mensagem contida no DNA, há uma singularidade biológica que se repete, mas se diferencia pelo modo como esta é organizada. Essa descrição corresponde à(s)

a) molécula de RNAr.

b) moléculas de RNAt.

c) bases nitrogenadas.

d) molécula de RNAm.

\section{Resultados e Discussão}

O teste de jogabilidade da Molécula Imobiliária foi realizado com um grupo de 24 discentes do $2^{\circ}$ ano do Ensino Médio, que tinham previamente visto o conteúdo de Genética durante o $1^{\circ}$ ano, em uma escola estadual no interior de Pernambuco, Brasil. Os alunos foram convidados para conhecer a proposta e experimentar o jogo. O objetivo deste teste foi verificar se a Molécula Imobiliária estava dentro da proposta e do público alvo (Figura 5). 
Figura 5. Fotos realizadas durante a validação da jogabilidade do jogo, onde podemos observar o tabuleiro (a), a construção da dupla fita com os nucleotídeos (b), os discentes lendo o cartão de sorte ou azar (c), e outros elementos do jogo como a ficha de perguntas e as moedas (d).

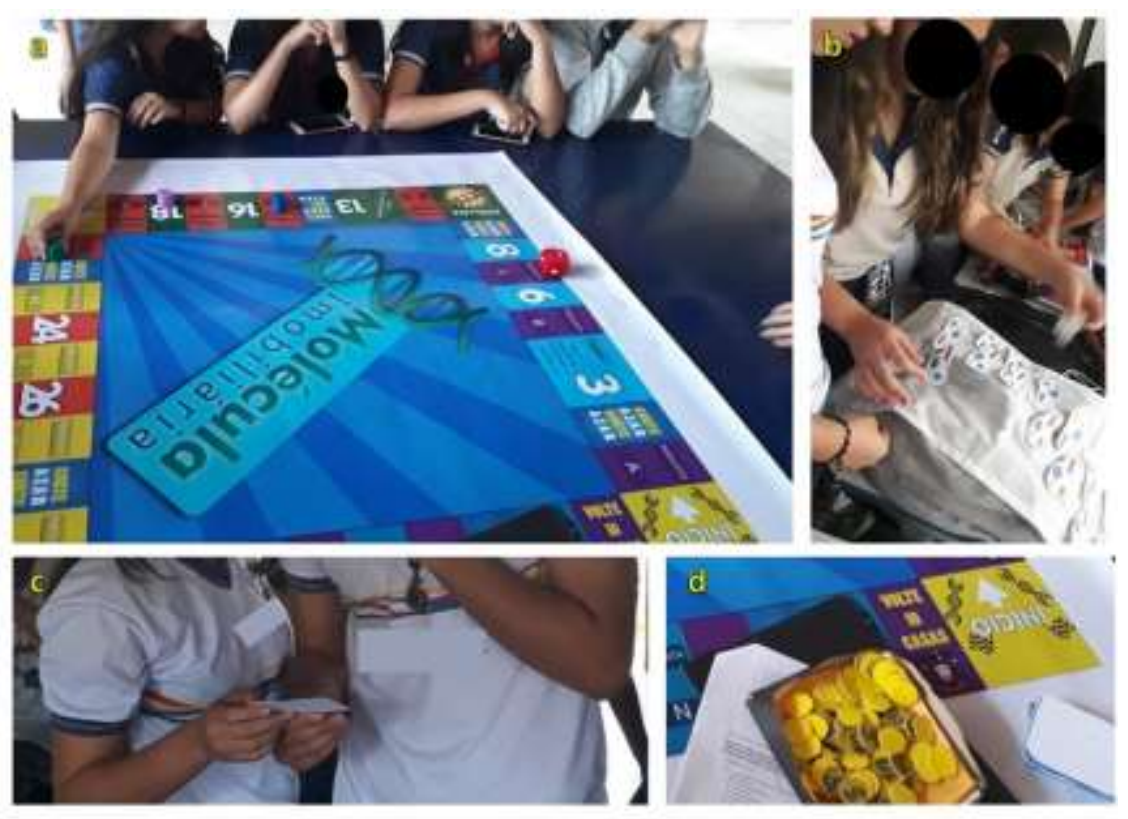

Fonte: Autores (2021).

O jogo foi aplicado no tempo de duas aulas (1h40min) e nesse teste de jogabilidade foi possível observar uma boa dinâmica e participação dos alunos. Eles participaram ativamente durante toda a aplicação do jogo, sendo significativa a interação dos estudantes com o modelo e com os indivíduos que faziam a intervenção. Santos (2018) afirma que esse interesse se deve à motivação despertada pelas atividades lúdicas ao alunado, o que incentiva a participação espontânea dos mesmos durante toda a aula. Outro tópico pertinente a ser citado, se refere aos representantes dos grupos. Essa estratégia demonstrou ser um bom método para uma maior organização no decorrer do jogo, tornando viável sua aplicabilidade em turmas maiores.

Em relação às perguntas, os alunos demonstraram um maior domínio na resolução das perguntas no decorrer do tabuleiro, ou seja, nas perguntas mais complexas e contextualizadas. Isso se deve ao fato que os mesmos haviam estudado os conteúdos abordados cerca de um ano antes, e já não recordavam de todos os conceitos básicos da Genética. Em decorrência disso, tiveram um menor desempenho nas perguntas diagnósticas, que foram as iniciais porque até então não havia tido intervenções.

Foi aproveitado o momento da aplicação das perguntas diagnósticas, na qual os alunos apresentaram pouco entendimento, para fazer uma breve revisão acerca do conteúdo. Em consequência disso, no segundo momento de perguntas mais complexas, os alunos conseguiram desenvolver melhor suas respostas e demonstraram um maior entendimento. Essa construção de conhecimento é destacada por Souza, Araújo, Zuza \& Costa (2013), que afirmam que a utilização do lúdico se comporta como uma alternativa de potencial, que promove a motivação no alunado e, consequentemente, oportuniza o conhecimento.

Esta motivação, segundo Amorim (2013), relaciona-se com o interesse e o desafio do aluno em relação ao modelo utilizado. O mesmo aponta que quanto mais interessado o aluno estiver, mais ele irá interagir com os demais alunos e isso, o estimulará a participar e repetir as etapas do jogo, influenciando consideravelmente no seu aprendizado.

Nesse sentido, foi observada a potencialidade do jogo como ferramenta didática para revisar conteúdos já apreendidos, 
uma vez que após a intervenção no primeiro momento do jogo, o rendimento dos alunos e a desenvoltura perante as respostas foi satisfatória.

Outro aspecto relevante foi o desenvolvimento de outras habilidades do alunado, como trabalho em equipe, e a capacidade de construção de conhecimentos de maneira conjunta aos colegas, não se restringindo ao professor, sendo estas, características pertinentes para serem levadas em consideração durante o processo de ensino-aprendizagem. Como Pedroso (2007) afirma, as atividades lúdicas podem proporcionar o desenvolvimento de capacidades de socialização, que vai estar relacionada às relações afetivas e de cooperação. Amorim (2013) complementa: "Além de facilitar a compreensão dos conteúdos abstratos, os jogos mostram-se adequados ao aprendizado dos alunos, pois favorecem motivação interna, raciocínio, argumentação e beneficia a relação aluno/aluno e professor/aluno".

\section{Considerações Finais}

A Molécula Imobiliária se mostrou uma excelente alternativa de modelo didático para contribuir no processo de ensino/aprendizagem sobre conteúdos de Genética no Ensino Eédio. Esta proposta de jogo demonstrou capacidade na contribuição da construção do conhecimento assim como, de outras habilidades relevantes para formação de um discente, como trabalho em equipe, liderança e colaboração. Portanto, podemos concluir que o jogo atende a sua proposta como instrumento didático facilitador e lúdico para o ensino da Genética e ainda contribui como alternativa metodológica docente perante as diversas aplicabilidades possíveis. Futuramente, esse jogo pode ser aplicado em uma sequência didática ou como instrumento avaliativo de ensino.

\section{Referências}

Amorim, A. S. (2013). A influência do uso de jogos e modelos didáticos no ensino de biologia para alunos de ensino médio. Monografia - Universidade Aberta do Brasil, Beberibe, Ceará.

Barnir, G. D. S. (2010). A importância e o sentido de estudar genética para estudantes do terceiro ano do ensino médio em uma escola da rede estadual de ensino em Gaspar (SC). Dissertação de mestrado - Universidade Regional de Blumenau, Blumenau, Santa Catarina, Brasil.

Benedetti, J., Diniz, R. \& Nishida, S. (2005). O jogo de representação (RPG) como ferramenta de ensino. Anais do I Encontro Nacional de Ensino de Biologia e III Encontro Regional de Ensino de Biologia da Regional, Rio de Janeiro.

Borém, A. \& Santos, F. R. (2001). Biotecnologia Simplificada. Editora Suprema.

Brandão, G. O. \& Ferreira, L. B. M. (2009). O ensino de Genética no nível médio: a importância da contextualização histórica dos experimentos de Mendel para o raciocínio sobre os mecanismos da hereditariedade. Filosofia e História da Biologia, 4, 43-63.

Brasil (1998). Parâmetros Curriculares Nacionais. MEC.

Brasil. (2013). Lei de Diretrizes e Bases da Educação Nacional. MEC/SEF.

Brussi, M. T. C. E. (2014). O Design Thinking como metodologia no processo de escolha e uso dos instrumentos de Comunicação Organizacional. (Trabalho de Conclusão, Universidade de Brasília, Brasília). https://bdm.unb.br/bitstream/10483/9347/1/2014_MariaThaisChavesEscobarBrussi.pdf

Bugallo, R. A. (1995). La Didáctica de la Genética: Revisión Bibliográfica. Enseñanza de las Ciencias, 3(13), 379-385.

Campos, L. M. L., Bortolotto, T. M. \& Felício, A. K. C (2003). A produção de jogos didáticos para o ensino de ciências e biologia: uma proposta para favorecer a aprendizagem. Caderno dos Núcleos de Ensino, 3548, 47-60.

Carboni, P. B. \& Soares, M. A. M. (2011). A genética molecular no ensino médio. http://www.gestaoescolar.diaadia.pr.gov.br/arqu ivos/File/pro ducoes _pde/artigo_patricia_berticelli_carboni.pdf

Conceição, A. R., Mota, M. D. A. \& Barguiu, P. M. (2020) Jogos didáticos no ensino e na aprendizagem de Ciências e Biologia: concepções e práticas docentes. Research Society and Development, 9(5), 1-26.

Fumagalli, L. (1998). O Ensino Fundamental de Ciências Naturais no Nível Fundamental da Educação Formal: Argumentos a seu favor. In: WEI.

Gil, A. C. (2017). Como elaborar projetos de pesquisa (5a ed.). Atlas. 
Research, Society and Development, v. 10, n. 4, e10310413890, 2021

(CC BY 4.0) | ISSN 2525-3409 | DOI: http://dx.doi.org/10.33448/rsd-v10i4.13890

Jann, P. N. \& Leite, M. F (2010). Jogo do DNA: um instrumento pedagógico para o ensino de ciências e biologia. Ciênc. Cogn., 15 (1), $282-293$.

Lewis, J. \& Wood-robinson, C. (2000). Genes, chromosomes, cell division and inheritance - do students see any relationship? International Journal of Science Education, 22(2), 177-195.

Luna, A. L. (2011). A importância do ensino de genética para o mundo atual. Trabalho de conclusão de curso, Universidade Federal do Paraná, Curitiba, Paraná. https://acervodigital.ufpr.br/handle/1884/32800

Moratori, P. B. (2003). Por que utilizar jogos educativos no processo de ensino aprendizagem. Trabalho de Conclusão, Universidade Federal do Rio de Janeiro, Baía de Guanabara, Rio de Janeiro.

Moreira, M. C. A. \& Silva, E. P. (2001). Concepções prévias: uma revisão de alguns resultados sobre Genética e Evolução. Anais do I Encontro regional de biologia, Niterói.

Neves, J. P., Campos, L. L. \& Simões, M. G. (2008). Jogos como recurso didático para o ensino de conceitos paleontológicos básicos aos estudantes do ensino fundamental. Terra plural, 2(1), 103-114.

Pedroso, C. V. (2009). Jogos didáticos no Ensino de Biologia: Uma proposta metodológica baseada em módulo didático. Anais do IX Congresso Internacional de Educação - EDUCERE, Curitiba, Paraná, Brasil.

Santos, R. O., Silva, P. S. \& Lima, J. L. S. (2018). Modelo didático como recurso para o ensino de ciências: sua influência como ferramenta facilitadora no processo de ensino aprendizagem. Vivências em ensino de Ciências, 2, 177-185.

Silveira, L. F. S. (2008). Uma contribuição para o ensino de genética. Dissertação de mestrado, Universidade Católica do Rio Grande do Sul, Porto Alegre, Rio grande do Sul, Brasil. https://repositorio.pucrs.br/dspace/handle/10923/3036

Silvia, J. C. S. \& Bianco, G. (2020). Jogos didáticos: a formação educativa através de uma aprendizagem significativa e um currículo adaptado por projetos. Research Society and Development, 9(9), 1-17.

Souza, J. P. P., Araújo, C. P., Zuza, H. O. B. B. \& Costa, I. A. S. (2013). Uso de jogos e modelos didáticos em Biologia: Uma proposta para consolidar conteúdos sobre microrganismos. IV Congresso Internacional de Educação, Porto Seguro, Bahia, Brasil.

Veloso, A. J. B (2003). Das ervilhas de Mendel à dupla hélice de Watson e Crick. Medicina Interna, 10 (3). 